\title{
Sürekli Ayaktan Periton Diyalizinde Nadir Bir Peritonit Nedeni: Aspergillus Niger
}

\author{
RARE CAUSE OF CONTINIOUS AMBULATORY PERITONEAL DIALYSIS ASSOCIATED \\ PERITONITIS: ASPERGILLUS NIGER
}

\author{
Alper AZAK ${ }^{1}$, Gülay KOÇAK ${ }^{2}$, Bülent HUDDAM ${ }^{3}$ \\ ${ }^{1}$ Balıkesir Devlet Hastanesi, Nefroloji Bölümü \\ ${ }^{2}$ Çanakkale Ondokuz Mart Üniversitesi, Nefroloji Kliniği \\ 3Muğla Üniversitesi Eğitim Ve Araştırma Hastanesi, Nefroloji Bölümü
}

Peritonit periton diyalizi hastalarında sık rastlanabilen çok önemli bir sağlık sorunudur. Hem iç hem de diş ortamda yaşayan bir mantar olmasına karşın, Aspergillus niger aspergillosis'in nadir bir nedenidir. (1). Aspergillus niger'e bağlı bir peritonit olgusu bildirilmektedir.

Nefrolithiasise sekonder son dönem böbrek yetmezliği nedeniyle 8 yıldır sürekli ayaktan periton diyalizi tedavisi (SAPD) görmekte olan, Balıkesir Devlet Hastanesi Nefroloji kliniğince takip edilen 57 yaşında erkek hasta karın ağrısı ve periton diyalizi sıvısında bulanıklaşma yakınması ile kliniğimize başvurdu. Öz geçmişinde 25 yıldır alkol bağımlığı vardı. Son 8 aydır periton diyalizi kliniğine gelişini aksattığı öğrenildi. Periton diyaliz sıvısından alınan örnekte beyaz küre sayısı mm3'de 2300, serum creaktif peptit düzeyi $90 \mathrm{mg} / \mathrm{dl}$ olarak ölçüldü. Ampirik olarak sefazolin ve gentamisin tedavisi intraperitoneal olarak başlandı. Periton sıvısından alınan ilk kültür örneğinde mikroorganizma belirlememesine karşın klinik bulgularının düzelmemesi nedeniyle 3. gün tedavisi vankomisin ve seftazidim olarak değiştirildi. Hastadan alınan ilk kültür örneği mantar besi yerine ekilmedi. Patojen izole edilememesi üzerine örnekler alınarak mantar besi yerine de ekim yapıldı. Alınan seri periton sıvı kültürlerinden tedavinin 5. günü Aspergillus niger izole edildi, duyarlılık testlerine göre amfoterisin B parenteral olarak başlandı ve periton diyalizi kateteri çıkarıldı, hemodiyaliz tedavisi ile izlendi. Hastanede yattığı süreçte parenteral tedavileri ve santral hemodiyaliz kateteri takılması ve pertion diyalizi kateterinin çıkarılması dışında invaziv girişim yapılmadı. Tedaviye karşın karın ağrısı ve klinik durumunda düzelme saptanmadı. Hasta tedavinin 24 . günü kaybedildi.

Uluslararası Periton Diyalizi Derneği (ISPD) kılavuzlarına göre mantar peritonitinin kültür veya mikroskobik olarak saptanmasından sonra acil olarak periton diyaliz kateterinin çıkarılması, kültür ve duyarlılık sonuçlarına göre tedavi düzenlenene kadar amfoterisin B ve 5flusitozin tedavisinin başlanılması önerilmektedir (2). Olgumuz kontrolsüz olduğu dönemde, öyküsünde antibiyotik kullanımı olmaması nedeniyle antibiyotik kullanımina ikincil olduğu düşünülmemiştir, periton diyaliz kateteri çıkarılarak kültür sonucuna göre amfoterisin B 
tedavisi başlanmıştır. SAPD ilişkili mantar peritonitleri nadir olmakla beraber çok yüksek ölüm riski ile beraberdir. Literatürde daha önce bildirilmiş olmakla beraber Aspergillus Niger'e bağlı mantar peritonitisi oldukça nadirdir. Tedaviye uyumsuzluk ve kronik alkol bağımlılığ1 bu olguda mantar peritonitine yol açan önde gelen nedenler olarak yorumlanmıştır.

\section{KAYNAKLAR}

1. Miles AM, Barth RH. Aspergillus peritonitis: therapy, survival, and return to peritoneal dialysis. Am J Kidney Dis 1995;26:80-83.

2. Warady BA, Bakkaloglu S, Newland J, et al. Consensus guidelines for the prevention and treatment of catheterrelated infections and peritonitis in pediatric patients receiving peritoneal dialysis: 2012 update. Perit Dial Int 2012;32:32-86. 